\title{
Disinfection booth: blessing or curse for spreading of COVID-19 in Bangladesh
}

\author{
Md Insiat Islam Rabby ${ }^{1}$ (D) - Farzad Hossain ${ }^{2}$. Ferdousi Akter $^{3} \cdot$ Riyazul Kabir Rhythm ${ }^{4} \cdot$ Tamanna Mahbub $^{5}$. \\ Syed Nazmul Huda ${ }^{6}$
}

Received: 22 July 2020 / Accepted: 18 August 2020 / Published online: 2 September 2020

(C) The Canadian Public Health Association 2020

\begin{abstract}
Dear Editor,
The utilization of disinfection booths in public places is a great threat for health. During the current COVID-19 pandemic, we noticed disinfection booths in public places of some countries, i.e., Bangladesh, India, Pakistan, and Turkey. Among these countries, disinfection booths are the most rapidly utilized machine in many public places along with government and non-government organizations in order to minimize the spreading rate of COVID-19. Basically, the installation of a disinfection booth is one attempt to disinfect passengers and avoid cross-infection inside the premises (Khan 2020). Such booths offer a 20-30-second overhead disinfectant shower. According to WHO, it can work on the surface but not on the human body and even has a harmful effect on the human body (Tamilarasu 2020). Therefore, WHO, US Centers for Disease Control (US CDC), Africa Centres for Disease Control and Prevention, and governments of different nations already recommended to stop using this type of booth, but it is still used in some countries, including Bangladesh.
\end{abstract}

Md Insiat Islam Rabby

insiatislam8@gmail.com

1 Faculty of Engineering, Department of Mechanical and Manufacturing Engineering, Universiti Putra Malaysia, 43400 Serdang, Selangor, Malaysia

2 Department of Mechanical and Production Engineering, Islamic University of Technology, Gazipur 1704, Bangladesh

3 Faculty of Human Ecology, Department of Social and Developmental Sciences, Universiti Putra Malaysia, 43400 Serdang, Selangor, Malaysia

4 Navana CNG Limited, Dhaka 1212, Bangladesh

5 Chittagong Medical College, Chattogram 4203, Bangladesh

6 Bangamata Sheikh Fojilatunnesa Mujib Science \& Technology University, Jamalpur 2000, Bangladesh
Therefore, healthcare organizations of the whole world need to be focused on this issue as no studies or scientific evidence concerning the effectiveness of a disinfection booth in preventing COVID-19 has yet been proved through comprehensive search. Furthermore, such booths utilize alcohol, bleach, chlorine solution, or chloroxylenol which are harmful to human health (Mallhi et al. 2020). Therefore, it is not advisable to fog or spray particular chemical products, i.e., quaternary ammonium compounds, chlorine-based agents, or formaldehyde. Meanwhile, according to the guidelines of the US CDC, registered disinfectants can only be utilized in the disinfecting and cleaning facilities under the United States Environmental Protection Agency (USEPA) (United States Environment Protection Agency (USEPA) 2020). Moreover, the Allergy Society of South Africa strongly condemns the use of a disinfection booth under any circumstances (Gray and van Niekerk 2020).

In fact, WHO clearly stated that the utilization of disinfection booths can be dangerous not only physically but also psychologically, and the practice does not minimize the risk of an infected person spreading the virus through touch or droplets (Foyez 2020). Moreover, according to one of the WHO advisories, chlorine spraying can cause irritation of the skin and eyes, as well as gastrointestinal symptoms such as nausea and vomiting, and sodium hypochlorite inhalations can lead to nose, throat, and respiratory irritation of the mucous membranes (Spraying of disinfectant on people "physically and psychologically harmful": Health ministry 2020).

Contrary to these advisories, disinfection booths are currently found in various renowned government and non-government organizations, shopping malls (i.e., Prince Bazar, Aarong), foot overbridges (i.e., New Market), and city streets of Bangladesh. Even some hospitals and police stations have installed them. To show the current scenario in Bangladesh, a few photos of different places that installed disinfection booths, from the newspaper and our personal collection, are presented in Figs. 1, 2, and 3. Figure 1, which we collected personally on 16 July 2020, shows a disinfection booth in front of a police station. Figs. 2 and 3 were 


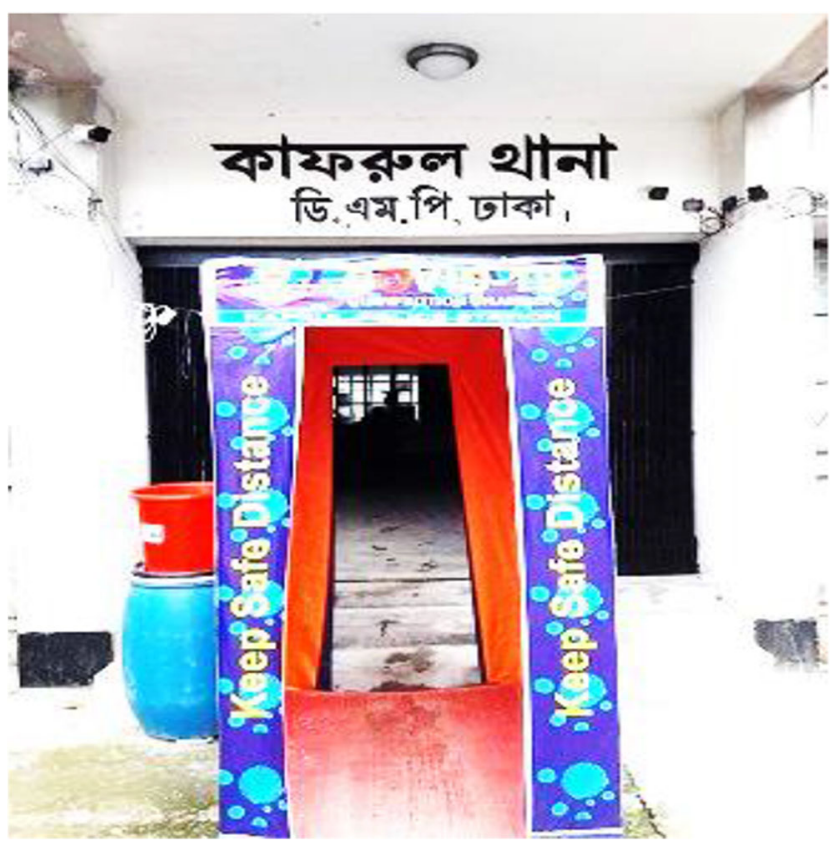

Fig. 1 Police station

taken from newspapers, with Fig. 2 showing a disinfection booth installed by the Bangladesh Army at the city street of Jashore for use by local people (Army installs disinfection booth in Jashore 2020). Fig. 3 shows a scenario of a disinfection booth that has been installed on the foot overbridge of a highly populated shopping mall-New Market (COVID-19: New Market traders install disinfection tunnels, resume business 2020). Bangladesh used these booths since April 2020 to minimize the COVID-19 spreading rate, but the infection statistics of COVID-19 from

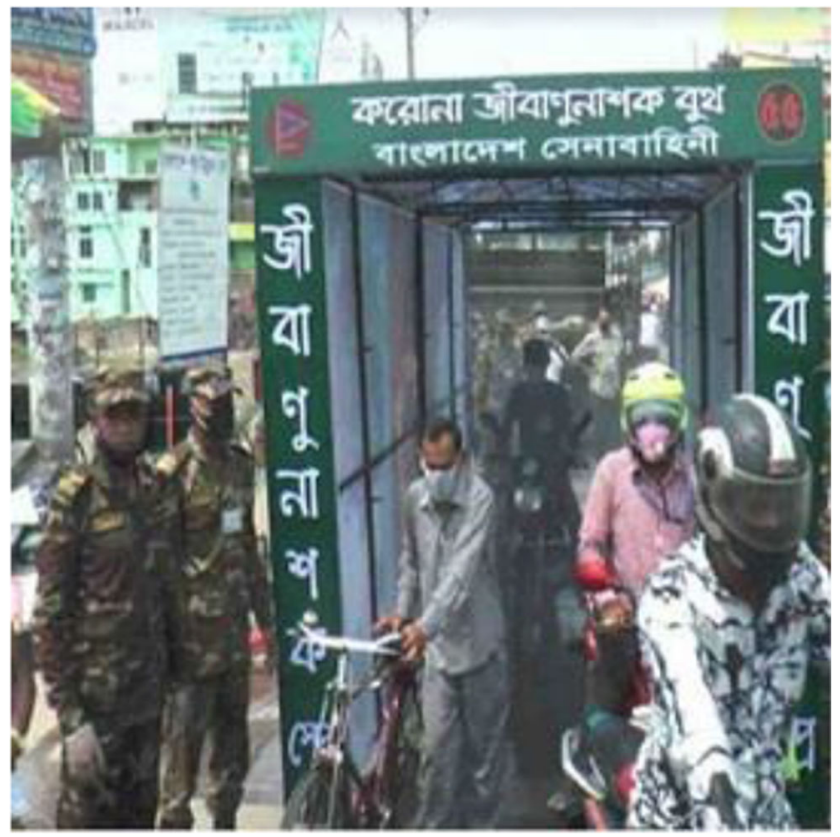

Fig. 2 City street (Army installs disinfection booth in Jashore 2020)

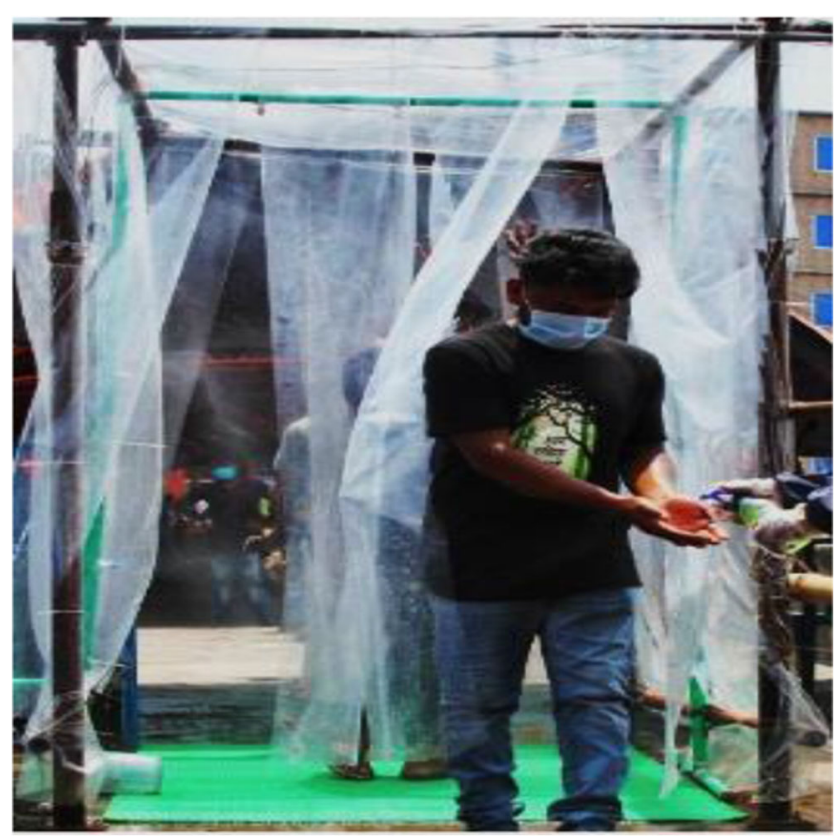

Fig. 3 Foot overbridge (COVID-19: New Market traders install disinfection tunnels, resume business 2020)

April 2020 to date do not show any noticeable reduction of spreading rate (Bangladesh Overview 2020).

In summary, evidence shows that the disinfection booth has no positive impact to reduce the spreading rate of COVID-19. Meanwhile, it has a negative impact on human health in some cases because of harmful chemicals when it is spread over the full body. Therefore, general people, higher authorities of government, and non-government organizations of Bangladesh need to be more concerned to follow COVID19 guidelines properly. In fact, we urge higher health authorities of Bangladesh and other nations as well to discourage the utilization of a disinfection booth and rather to emphasize the necessity of proper hand hygiene, wearing of masks, and using physical distancing for preventing the spread of COVID-19 among the general public.

\section{References}

Army installs disinfection booth in Jashore. UNB News. Retrieved from: https://unb.com.bd/category/Bangladesh/army-installs-disinfectionbooth-in-jashore/49911. Accessed: 16 July 2020.

Bangladesh Overview. Corona tracer. Retrieved from: https://www. coronatracker.com/country/bangladesh/. Accessed: 16 July 2020.

COVID-19: New Market traders install disinfection tunnels, resume business. UNB News. Retrieved from: https://unb.com.bd/category/ Bangladesh/covid-19-new-market-traders-install-disinfectiontunnels-resume-business/51864. Accessed: 16 July 2020.

Foyez, A., 'Disinfection tunnel' harmful: WHO. New Age Bangladesh Retrieved from: https://www.newagebd.net/article/107308/ disinfection-tunnel-harmful-who. Accessed: 16 July 2020.

Gray, C. L., van Niekerk, A., (2020) The use of disinfection tunnels or disinfectant spraying of humans as a measure to reduce the spread of the SARS-CoV-2 virus. S Afr Med J 110(8). 
Khan A, (2020). Fad or future? Experts question efficacy of disinfection gates. The Express Tribune. Retrieved from: https://tribune.com.pk/ index.php/story/2207681/fad-future-experts-question-efficacydisinfection-gates. Accessed: 15 July 2020.

Mallhi TH, Khan YH, Alotaibi NH, Alzarea AI. Walkthrough sanitization gates for COVID-19: a preventive measure or public health concern?. The American Journal of Tropical Medicine and Hygiene. 2020 Jun 3:tpmd200533. https://doi.org/10.4269/ajtmh. 20-0533.

Spraying of disinfectant on people "physically and psychologically harmful": Health ministry. Outlook - The News Scroll. Retrieved from: https://www.outlookindia.com/newsscroll/spraying-of-disinfectanton-people-physically-and-psychologically-harmful-health-ministry/ 1807129, Accessed: 16 July 2020.
Tamilarasu, P., COVID-19 disinfectant tunnels may harm humans more than virus. The Federal. Retrieved from: https:/thefederal.com/ states/south/tamil-nadu/covid-19-sodium-hypochlorite-tunnelsmay-harm-humans-more-than-virus/. Accessed: 16 July 2020.

United States Environment Protection Agency (USEPA). Disinfectants for used against SARS-Co-V. Retrieved from: https://www.epa.gov/ pesticide-registration/list-n-disinfectants-use-against-sars-cov-2. Accessed: 16 July 2020.

Publisher's note Springer Nature remains neutral with regard to jurisdictional claims in published maps and institutional affiliations. 